American Journal of Applied Science 4 (7): 465-478, 2007

ISSN 1546-9239

(C) 2007 Science Publications

\title{
Assessment of Canadian Regulations and Remediation Methods for Diesel Oil Contaminated Soils
}

\author{
D. G. Rushton, A. E. Ghaly and K. Martinell \\ Department of Process Engineering and Applied Science, Dalhousie University \\ Halifax, Nova Scotia, Canada, B3J 2X4
}

\begin{abstract}
Diesel fuel released into the environment can contaminate ground water, degrade potable water supplies and cause the collapse of fisheries. They are toxic to both animals and humans and can affect the liver, lungs, kidneys, and nervous system leading to cancer as well as immunological and reproductive effects. The objectives of this study were to review current Canadian regulations pertaining to diesel fuel and to evaluate the current remediation methods using five criteria: efficiency, applicability, cost, time and cleanliness. PAHs are deemed toxic under the Canadian Environmental Protection Act but no standards have been set for PAHs in diesel. The Canadian Council of Ministers of the Environment (CCME) has developed Canada-Wide Standards for Petroleum Hydrocarbons in Soil (CWS PHCS) while the Atlantic PIRI has implemented a Risk Based Corrective Action (RBCA) for the Atlantic region. The remediation methods included soil washing, landfilling, incineration, thermal desorption, radio frequency heating, chemical addition, landfarming, biopiling, composting, bioventing, liquid delivery and bioreactors. The bioreactors studied included: static bed, continuous mix, horizontal drum, fungal compost, slurry-phase, DITS, biofilters and packed bed bioreactors. The results showed that the biological methods were more effective than nonbiological ones and the bioreactors scored the highest among the biological methods. Eight criteria were then used for the evaluation of bioreactors: efficiency, time, cost, maintenance, simplicity, release of VOCs to the atmosphere, containment of contaminants and control of operating parameters The results showed that the continuous mix bioreactor was the most effective system.
\end{abstract}

Key words: Diesel fuel, remediation, regulation, ecosystem, physical, chemical, biological, evaluation

\section{INTRODUCTION}

Diesel Fuel is intended for use in compression engines such as those found in trucks, trains and subtrains ${ }^{[1]}$. It is composed of a variety of organic compounds as shown in Table $1^{[2]}$. As the fuel weathers over time, the concentration of these compounds change due to volatilization and degradation to other compounds ${ }^{[3]}$.

Accidental diesel spills and the leakage of underground storage tanks have far reaching impacts on the environment. A study on marine iguanas on one of the Galapagos Islands in Ecuador has shown that $62 \%$ of the species population has died since the oil tanker spill that occurred $1500 \mathrm{~m}$ offshore in $2001^{[4]}$. There are over 400000 petroleum hydrocarbon contaminated sites in the USA alone as a result of spillage and leakage of underground tanks located at airports, refineries and farms ${ }^{[5]}$. Pockets of oil on these sites can persist in the environment for many years. The study on the $700000 \mathrm{~L}$ diesel spill of 1969 (which is only one sixtieth of that spilled by Exxon Valdez) is still going on by Woods Hole Oceanographic Institute of Massachusetts $^{[6]}$.

According to Riser-Roberts ${ }^{[2]}$, hydrocarbons in the soil are considered toxic when they reach concentrations greater that $100 \mu \mathrm{g} / \mathrm{g}$ soil. The soluble compounds of diesel (benzene, toluene, ethyl benzene, and xylenes which are known as BTEX) are toxic to aquatic life as well as animals and humans. Diesel released into the environment can contaminate ground water, degrade potable water supplies and cause the collapse of fisheries ${ }^{[3]}$. Polycyclic aromatic hydrocarbons (PAHs) in diesel (such as naphthalene) have long term effects on soil, ground water and sediments and can act as endocrine disruptors (i.e. interfere with hormone production and function). The PAHs and BTEX affect the liver, lungs, kidneys and nervous system leading to cancer, immunological, reproductive, fetotoxic and genotoxic effects ${ }^{[1]}$.

Corresponding Author: Abdel Ghaly, Department of Process Engineering and Applied Science, Dalhousie University, Halifax, Nova Scotia, Canada, B3J 2X4; Tel: 902-494-6014; Fax: 902-420-7639 
$\mathrm{CCME}^{[7]}$ summarizes the pathways through which humans and wildlife can be exposed to contaminants (Table 2).

Table 1: Composistion of Diesel Fuel \#2 $2^{[2]}$

\begin{tabular}{lc}
\hline Component $_{10}$ & Concentration (\% Volume) \\
\hline $\mathrm{C}_{10}$ paraffins & 0.9 \\
$\mathrm{C}_{10}$ aromatics & 0.4 \\
$\mathrm{C}_{10}$ cycloparaffins & 0.6 \\
$\mathrm{C}_{11}$ paraffins & 2.3 \\
$\mathrm{C}_{11}$ aromatics & 1.0 \\
$\mathrm{C}_{11}$ cycloparaffins & 1.7 \\
$\mathrm{C}_{12}$ paraffins & 3.8 \\
$\mathrm{C}_{12}$ aromatics & 1.6 \\
$\mathrm{C}_{12}$ cycloparaffins & 2.8 \\
$\mathrm{C}_{13}$ paraffins & 6.4 \\
$\mathrm{C}_{13}$ aromatics & 2.8 \\
$\mathrm{C}_{13}$ cycloparaffins & 4.8 \\
$\mathrm{C}_{14}$ paraffins & 8.8 \\
$\mathrm{C}_{14}$ aromatics & 3.8 \\
$\mathrm{C}_{14}$ cycloparaffins & 6.6 \\
$\mathrm{C}_{15}$ paraffins & 7.4 \\
$\mathrm{C}_{15}$ aromatics & 3.2 \\
$\mathrm{C}_{15}$ cycloparaffins & 5.5 \\
$\mathrm{C}_{16}$ paraffins & 5.8 \\
$\mathrm{C}_{16}$ aromatics & 2.5 \\
$\mathrm{C}_{16}$ cycloparaffins & 4.4 \\
$\mathrm{C}_{17}$ paraffins & 5.5 \\
$\mathrm{C}_{17}$ aromatics & 2.4 \\
$\mathrm{C}_{17}$ cycloparaffins & 4.1 \\
$\mathrm{C}_{18}$ paraffins & 4.3 \\
$\mathrm{C}_{18}$ aromatics & 1.8 \\
$\mathrm{C}_{18}$ cycloparaffins & 3.2 \\
$\mathrm{C}_{19}$ paraffins & 0.7 \\
$\mathrm{C}_{19}$ aromatics & 0.3 \\
$\mathrm{C}_{19}$ cycloparaffins & 0.6 \\
\hline &
\end{tabular}

\section{CANADIAN REGULATIONS}

Federal Regulations: Many of the regulations that pertain to diesel fuel in Canada relate to its sulphur content ${ }^{[8]}$, since the production of $\mathrm{SO}_{2}$ during combustion and exhaust is the leading cause of acid rain. However, diesel-powered vehicles are a significant source of aromatic hydrocarbons in urban areas. Human exposure to diesel containing benzene at any concentration will have adverse health effects. Although PAHs (like benzene) are considered toxic under the Canadian Environmental Protection Act (CEPA), there are no standards for PAHs in diesel ${ }^{[9]}$. CEPA regulations apply to quantities greater than 400 $\mathrm{m}^{3}$ of fuel produced or imported into Canada that contains any additives. The petroleum industry is required to report sulphur content and any additives in the fuel, other than lead, to the Minister of Environment, where the liquid fuel is from crude oils, coal, or bituminous sands.

Many factors affect the cost of the diesel clean-up in Canada including: (a) the accessibility or remoteness of the spill location, whether the spill is located on land, in a river, or in the ocean, (b) the weather conditions, (c) the quantity spilled, (d) the extent of environmental damage, and (e) the time required for the clean-up. Blondeau $^{[10]}$ reported that, based on the data obtained from the Saskatchewan Spill Response Center, the leading causes of spills are equipment failure and accidents during road transport and most of the spills documented were from petroleum, transportation and mining companies.

About $60 \%$ of Canada's contaminated sites involve petroleum hydrocarbons (PHCs) that can cause fires and/or explosions on these sites and impair the quality and uses of land and water. The Canadian Council of Ministers of the Environment (CCME) developed Canada-Wide Standards for Petroleum Hydrocarbons in Soil (CWS PHCS) in 2001 ${ }^{[7]}$. These standards separate soil under four different land uses: agricultural, residential/parkland, commercial, and industrial. Table 3 shows the allowable petroleum hydrocarbon (PHC) fractions in soil, depending on the land use. The CWS PHCS specifies the methods and outcomes for the assessment and management of contaminated sites but timelines are left for individual jurisdictions to decide. When assessing a contaminated site, one must also consider ignition hazards, toxicity, odor, appearance of the contaminants, effects on buried infrastructure, and formation of non-aqueous-phase liquids (NAPL). Table 4 shows the required site characterization. All provinces and territories except Quebec have endorsed CWS PHCS and the legislation for its enforcement.

Regulations in the Atlantic Region: The Atlantic Provinces (Nova Scotia, New Brunswick, Prince Edward Island, and Newfoundland and Labrador) have a harmonizing partnership agreement called the Risk Based Corrective Action (RBCA) agreement with its own set of PHC guidelines. The Atlantic Partnership in RBCA Implementation (PIRI) ensures that RBCA is effective and serves the needs of Atlantic Canadians by returning more sites to safe use at a reduced cost. The RBCA has been in use since 1999 and it differs from the CWS PHCS with respect to criteria for laboratory procedures for the comparison of site data ${ }^{[11]}$.

RBCA is a 3-tiered approach to risk assessment and risk management. Tier I uses the risk-based screening levels from Table 5 to determine the need for and the extent of removal of any remedial work required after confirmation of site applicability. It identifies the presence of ecological receptors on or adjacent to the site (within $150 \mathrm{~m}$ ) and the potential for ecological receptors to be exposed to the release of 
hydrocarbons. Tier II uses the values from Table 6 to determine the need for and the extent of remedial work required. Tier III is triggered by an ecological risk assessment, even if human health risk is managed under RBCA. RBCA is used in residential and commercial land use settings and adult is the default receptor ${ }^{[11]}$.

\section{REMEDIATION METHODS}

Soil remediation can take place either in-situ or ex-situ using one or more of the current remediation technologies. These include: physical, thermal, chemical and biological processes ${ }^{[2]}$.

Physical Processes: Physical remediation technologies include soil washing and landfilling.

Soil washing: Soil washing is when a wash solution (water and/or a surfactant) is added to soil to remove contaminants. The contaminant is transferred from the soil to the wash solution, which then must be treated. Residual sludge is often associated with this method. Water alone is not effective in removing PAHs. Haapea and Tuhkanen ${ }^{[12]}$ reported that the amount of total PAHs in the soil decreased by about $50 \%$ after soil washing as the PAHs were transferred into the washing water. Viglianti et al. $^{[13]}$ found the addition of cyclodextrins significantly improved the soil washing process. Rajput et al. ${ }^{[14]}$ used soil washing to remove 1,2,4-trichlorobenzene (TCB), aniline, phenol, and 2,4dichlorophenol (DCP) and found water washing to be suitable for removing all contaminants except TCB which required washing with surfactant first and then rinsing with water. Other solutions such as hydrochloric acid and sodium hydroxide have also been used in soil washing techniques ${ }^{[15,16]}$.

Landfilling: Landfilling is one of the oldest forms of remediation. Contaminated soil is excavated from the site and transported to a landfill where it remains indefinitely. In cases where the soil is brought to a first generation landfill, there is still the potential for the contaminants to enter groundwater or bedrock. PAHs can contaminate landfill leachate and their presence has been reported ${ }^{[17,18]}$. However, methods have been devised for the removal of aromatic organics from soil which may help to control these contaminants in landfills ${ }^{[19]}$.

Thermal Processes: There are currently three thermal remediation technologies in use: incineration, thermal desorption and radio frequency heating.

Incineration: Incineration is the destruction of contaminants by burning contaminated soil. This method can achieve greater than $99.99 \%$ success in destroying carbon tetrachloride, chlorinated benzenes and polychlorinated biphenyls but is very expensive $\mathrm{e}^{[2]}$. Benzene is adequately destructed via thermal incineration at temperatures ranging from 850 to 973 $\mathrm{K}^{[20]}$. However, catalytic incineration is more efficient than thermal incineration in destroying aromatic hydrocarbons. $\mathrm{CuO} / \mathrm{CeO}_{2}$ and $\mathrm{CuO} / \gamma-\mathrm{Al}_{2} \mathrm{O}_{3}$ were found to be effective catalysts in the incineration of toluene and $p$-xylene ${ }^{[21-23]}$. Arsenijević et al. ${ }^{[24]}$ used a $\mathrm{Pt} / \mathrm{Al}_{2} \mathrm{O}_{3}$ catalyst to incinerate ethylene oxide. Tseng and $\mathrm{Chu}^{[25]}$ studied the catalytic incineration of styrene (also known as vinyl benzene) using $\mathrm{MnO} / \mathrm{Fe}_{2} \mathrm{O}_{3}$ as a catalyst.

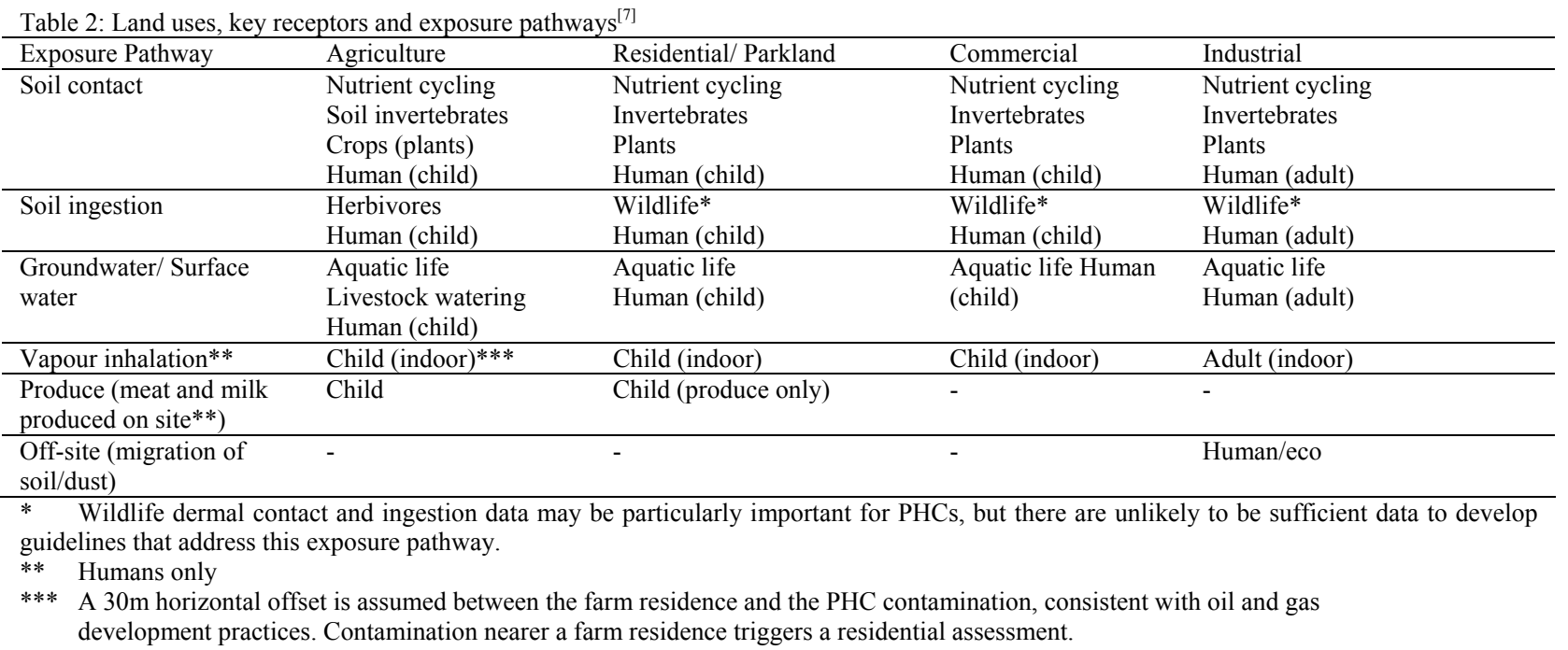


Am. J. Applied Sci., 4 (7): 465-478, 2007

Table 3: Tier 1 levels for surface soil

\begin{tabular}{llllll}
\hline \multirow{2}{*}{ Land Use } & & \multicolumn{3}{c}{ PHC $(\mathrm{mg} / \mathrm{kg})$} \\
\cline { 3 - 6 } Agricultural & Soil Texture & Fraction 1 & Fraction 2 & Fraction 3 & Fraction 4 \\
& Coarse & 130 & $450\left(150^{\mathrm{a}}\right)$ & 400 & 2800 \\
& Fine & $260\left(180^{\mathrm{b}}\right)$ & $900\left(250^{\mathrm{b}}\right)$ & 800 & 5600 \\
\hline Residential/ Parkland & Coarse & $30^{\mathrm{c}}$ & $150^{\mathrm{c}}$ & 400 & 2800 \\
& Fine & $260\left(180^{\mathrm{b}}\right)$ & $900\left(250^{\mathrm{b}}\right)$ & 800 & 5600 \\
\hline Commercial & Coarse & $310\left(230^{\mathrm{a}}\right)$ & $760\left(150^{\mathrm{a}}\right)$ & 1700 & 3300 \\
& Fine & $660\left(180^{\mathrm{b}}\right)$ & $1500\left(250^{\mathrm{b}}\right)$ & 2500 & 6600 \\
\hline Industrial & Coarse & $310\left(230^{\mathrm{a}}\right)$ & $760\left(150^{\mathrm{a}}\right)$ & 1700 & 3300 \\
& Fine & $660\left(180^{\mathrm{b}}\right)$ & $1500\left(250^{\mathrm{b}}\right)$ & 2500 & 6600 \\
\hline
\end{tabular}

${ }^{a}$ Where applicable, for protection against contaminated groundwater discharge to an adjacent surface water body.

${ }^{b}$ Where applicable, for the protection of potable groundwater. ${ }^{\mathrm{c}}$ Assumes contamination near residence with slab-on-grade construction.

Table 4: Site characterization

\begin{tabular}{|c|c|c|c|c|c|c|c|c|c|}
\hline \multicolumn{2}{|l|}{ Characteristics } & \multicolumn{8}{|l|}{ Description } \\
\hline \multicolumn{2}{|l|}{ Land use } & \multicolumn{8}{|c|}{$\begin{array}{l}\text { Historical, existing, intended, and potential land uses at the site and its surroundings, including the presence or } \\
\text { absence of any critical wildlife habitat }\end{array}$} \\
\hline \multicolumn{2}{|l|}{ Proximity } & \multicolumn{8}{|c|}{ Distance between the site and surface water especially drinking water supplies } \\
\hline \multicolumn{2}{|l|}{ Groundwater } & \multicolumn{8}{|c|}{ Depth of ground water } \\
\hline \multicolumn{2}{|c|}{ Human receptors } & \multicolumn{8}{|c|}{ Children and adults } \\
\hline \multicolumn{2}{|c|}{ Ecological receptors } & \multicolumn{8}{|c|}{ Microorganisms responsible for nutrient cycling, soil invertebrates, plants, wildlife, and aquatic life } \\
\hline \multicolumn{2}{|c|}{ Exposure pathways } & \multicolumn{8}{|c|}{$\begin{array}{l}\text { Soil contact, soil ingestion, groundwater/ surface water, vapor inhalation, produce, meat and milk produced on site, } \\
\text { and off-site migration of soil/dust }\end{array}$} \\
\hline \multicolumn{2}{|l|}{ Stratography } & \multicolumn{8}{|c|}{ Properties of surficial materials, especially soil texture } \\
\hline \multicolumn{2}{|c|}{ Depth to contamination } & \multicolumn{8}{|c|}{ Distance to points of exposure or compliance } \\
\hline \multicolumn{2}{|c|}{ Built environment } & \multicolumn{8}{|c|}{ The presence and type of buildings, utility corridors, and conduits } \\
\hline \multicolumn{2}{|l|}{ Contaminants } & \multicolumn{8}{|c|}{ Characterization and delineation of contaminants such as toxicity, ignitability, solubility and volatility } \\
\hline \multicolumn{10}{|c|}{ Table 5: Tier I TBSL for soil ${ }^{[11]}$} \\
\hline \multirow[t]{3}{*}{ Receptor } & \multirow{3}{*}{$\begin{array}{l}\text { Groundwater } \\
\text { Use }\end{array}$} & \multirow{3}{*}{$\begin{array}{l}\text { Soil } \\
\text { Type }\end{array}$} & \multicolumn{7}{|c|}{ Compound of concern in soil $(\mathrm{mg} / \mathrm{kg})$} \\
\hline & & & \multirow[t]{2}{*}{ Benzene } & \multirow[t]{2}{*}{ Toluene } & \multirow[t]{2}{*}{ Ethyl Benzene } & \multirow[t]{2}{*}{ Xylenes } & \multicolumn{3}{|c|}{ Modified TPH } \\
\hline & & & & & & & Gas & Diesel/\#2 & $\# 6$ oil \\
\hline \multirow[t]{4}{*}{ Residential } & Potable & Coarse & 0.03 & 0.38 & 0.08 & 11 & 39 & 140 & 690 \\
\hline & & Fine & 0.01 & 0.08 & 0.02 & 2.3 & 140 & 220 & 970 \\
\hline & Non-potable & Coarse & 0.16 & 14 & 58 & 17 & 39 & 140 & 690 \\
\hline & & Fine & 1.5 & 120 & 430 & 160 & 330 & 4400 & 8300 \\
\hline Commercial & Potable & Coarse & 0.03 & 0.38 & 0.08 & 11 & 450 & 7400 & 10000 \\
\hline & & Fine & 0.01 & 0.08 & 0.02 & 2.3 & 520 & 840 & 4700 \\
\hline & Non-potable & Coarse & 1.8 & 160 & 430 & 200 & 450 & 7400 & 10000 \\
\hline & & Fine & 11 & 680 & 430 & 650 & 10000 & 7700 & 10000 \\
\hline
\end{tabular}

Everaert and Baeyens ${ }^{[26]}$ review catalytic oxidation processes for volatile organic contaminants (VOCs).

Thermal desorption: In thermal desorption, soil is heated under an inert atmosphere to increase the vapor pressure of organic contaminants causing the contaminants to volatilize and be released from the soil ${ }^{[27]}$. Merino and Bucala ${ }^{[28]}$ reported that hexadecane can be nearly completely removed at $300^{\circ} \mathrm{C}$ without risk of pyrolysis. Piña et al. ${ }^{[29]}$ found that low heating rates practically eliminate gas oil from soil matrices while avoiding significant chemical transformations but higher temperatures were required to achieve optimal removal efficiencies.
Radio frequency heating: Radio frequency power has been used in the steam reforming of hydrocarbons. These waves are converted to thermal energy in the soil for heating the contaminants and causing their volatilization. This procedure is very expensive but because the heat can be directed, the treatment is more accurate $^{[2]}$. Al-Mayman and Al-Zahrani ${ }^{[30]}$ cracked Saudi light oil into lower olefins using radio frequency heating. Shih et al. ${ }^{[31]}$ decomposed benzene $\left(\mathrm{C}_{6} \mathrm{H}_{6}\right)$ in radio frequency plasma environments and found naphthalene $\left(\mathrm{C}_{10} \mathrm{H}_{8}\right)$ to be a predominant product.

Chemical Processes: Peroxide or an alkaline solution with a $\mathrm{pH}$ of 10.5 containing cobalt (III) can be added to contaminated soil to oxidize organic contaminants to 
Table 6: Tier II Pathway-Specific Screening Level (PSSL) for soil ${ }^{[1]}$

\begin{tabular}{|c|c|c|c|c|c|c|c|c|c|c|c|}
\hline \multirow[t]{3}{*}{ Receptor } & \multirow[t]{3}{*}{ Groundwater Use } & \multirow[t]{3}{*}{ Soil Type } & \multirow{3}{*}{$\begin{array}{l}\text { Exposure } \\
\text { Pathway }\end{array}$} & \multicolumn{8}{|c|}{ Compound of concern in soil $(\mathrm{mg} / \mathrm{kg})$} \\
\hline & & & & \multirow[t]{2}{*}{ Benzene } & \multirow[t]{2}{*}{ Toluene } & & \multirow[t]{2}{*}{ Ethyl Benzene } & \multirow[t]{2}{*}{ Xylenes } & \multicolumn{3}{|c|}{ Modified TPH } \\
\hline & & & & & & & & & Gas & Diesel/\#2 & \#6 oil \\
\hline \multirow[t]{11}{*}{ Residential } & \multirow[t]{6}{*}{ Potable } & \multirow[t]{3}{*}{ Coarse } & Soil ingestion & 390 & 12000 & & 7000 & 120000 & 8900 & 5300 & 8300 \\
\hline & & & Soil leaching & 0.031 & 0.38 & & \multirow{2}{*}{$\begin{array}{l}0.083 \\
>430\end{array}$} & 11 & 680 & 1100 & 8300 \\
\hline & & & Indoor air & 1.5 & 120 & & & 160 & 330 & 4400 & $>$ RES \\
\hline & & Fine & Soil ingestion & 390 & 12000 & & & 120000 & 8900 & 5300 & 8300 \\
\hline & & & Soil leaching & 0.0071 & 0.082 & & 0.018 & 2.3 & 140 & 220 & 970 \\
\hline & & & Indoor air & 0.16 & 14 & & 58 & 17 & 39 & 140 & 690 \\
\hline & \multirow{5}{*}{ Non-potable } & & Soil leaching & Not appli & ble for no & scenarios & 7000 & & & & \\
\hline & & & Indoor air & 1.5 & 120 & & $>430$ & 160 & 330 & 4400 & $>$ RES \\
\hline & & Fine & Soil ingestion & 390 & 12000 & & \multirow[t]{2}{*}{7000} & 120000 & 8900 & 5300 & 8300 \\
\hline & & & Soil leaching & Not appli & ble for no & scenarios & & & & & \\
\hline & & & Indoor air & 1.8 & 160 & & $>430$ & 200 & 450 & 7400 & $>$ RES \\
\hline \multirow[t]{10}{*}{ Commercial } & \multirow[t]{4}{*}{ Potable } & Coarse & Soil ingestion & 570 & 18000 & & 10000 & 180000 & 13000 & 7700 & 12000 \\
\hline & & & Soil leaching & 0.031 & 0.38 & & 0.083 & 11 & 2500 & 11000 & $>$ RES \\
\hline & & & Indoor air & 11 & $>680$ & & $>430$ & $>650$ & $>$ RES & $>$ RES & $>$ RES \\
\hline & & Fine & Soil ingestion & 570 & 18000 & & 10000 & 180000 & 13000 & 7700 & 12000 \\
\hline & Non-potable & Coarse & Soil ingestion & 570 & 18000 & & 10000 & 180000 & 13000 & 7700 & 12000 \\
\hline & & & Soil leaching & Not appli & ble for no & scenarios & & & & & \\
\hline & & & Indoor air & 11 & & $>680$ & $>430$ & $>650$ & $>$ RES & $>$ RES & $>$ RES \\
\hline & & Fine & Soil ingestion & 570 & & 18000 & 10000 & 180000 & 13000 & 7700 & 12000 \\
\hline & & & Soil leaching & Not appli & ble for no & scenarios & & & & & \\
\hline & & & Indoor air & 0.16 & & 14 & 17 & 39 & & 140 & 90 \\
\hline
\end{tabular}

Table 7: Advantages and disadvantages of nonbiological methods ${ }^{[67]}$

\begin{tabular}{|c|c|c|}
\hline Process & Advantages & Disadvantages \\
\hline Soil Washing & $\begin{array}{l}\text { Relatively efficient } \\
\text { Quick } \\
\text { Uses water }\end{array}$ & $\begin{array}{l}\text { Transfers contaminants to a different phase } \\
\text { Surfactants are often necessary } \\
\text { Requires infrastructure }\end{array}$ \\
\hline Landfilling & Removes contamination from site & $\begin{array}{l}\text { Transfers pollution to another site } \\
\text { Expensive } \\
\text { Land requirement } \\
\text { Transportation costs }\end{array}$ \\
\hline Incineration & $\begin{array}{l}\text { Quick } \\
\text { Destroys hydrocarbons }\end{array}$ & $\begin{array}{l}\text { Expensive } \\
\text { Can cause air pollution } \\
\text { Irreversible soil degradation }\end{array}$ \\
\hline Thermal Desorption & $\begin{array}{l}\text { Broad applicability } \\
\text { High removal efficiencies } \\
\text { No excavation required in situ }\end{array}$ & $\begin{array}{l}\text { At high temperatures contaminants may volatilize and are released } \\
\text { from the soil into the air } \\
\text { Low temperatures do not achieve optimal removal efficiencies } \\
\text { Energy use }\end{array}$ \\
\hline Radio Frequency Heating & Accurate & $\begin{array}{l}\text { Very expensive } \\
\text { Products must be disposed of }\end{array}$ \\
\hline Chemical Addition & $\begin{array}{l}\text { Simple } \\
\text { Oxidizes organic contaminants } \\
\text { Soil left intact }\end{array}$ & $\begin{array}{l}\text { Extracts must be treated } \\
\text { Excavation }\end{array}$ \\
\hline
\end{tabular}

$\mathrm{CO}_{2}$ and $\mathrm{CO}$. Supercritical water can also be used to oxidize hazardous materials ${ }^{[32-34]}$. Acetone, methanol and ethanol solutions can then be used to extract compounds like benzene and pyrene ${ }^{[2,35]}$.

Biological Processes: There are a number of biological technologies currently in use: landfarming, biopiling, composting, bioventing and liquid delivery. It should be noted that hydrocarbon concentrations of less than 10 $\mu \mathrm{g} / \mathrm{l}$ do not usually stimulate microbial growth ${ }^{[2]}$ and hydrocarbons with rings or many branches are slower to biodegrade ${ }^{[36]}$. Ghaly and Pyke ${ }^{[37]}$ reported that hydrocarbons with heavy molecular weight $\left(\mathrm{C}_{12} \mathrm{H}_{12^{-}}\right.$ $\left.\mathrm{C}_{31}-\mathrm{C}_{64}\right)$ are slower to biodegrade.

Landfarming: Millions of tons of contaminated soil are treated by landfarming annually in the USA and Canada and more than half of which is associated with petrochemical contaminants. The processes involved with this method of treatment include: leaching, adsorption, desorption, photodecomposition, oxidation, hydrolysis, and biological metabolism ${ }^{[2]}$. Aeration and 
Am. J. Applied Sci., 4 (7): 465-478, 2007

Table 8: Advantages and disadvantages of land based biological methods

\begin{tabular}{|c|c|c|}
\hline Process & Advantages & Disadvantages \\
\hline Landfarming & Least expensive, can be performed ex-situ or in-situ & $\begin{array}{l}\text { Long residence time, unsuitable in towns (large land area } \\
\text { required), potential for contaminating water, air, soil, sensitive to } \\
\text { weather, limited capability in degrading complex compounds, } \\
\text { possibility of contaminant transport, requires less than } 2 \% \text { grade } \\
\text { slope }\end{array}$ \\
\hline Biopiling & $\begin{array}{l}\text { Effective nutrient supplementation, second least } \\
\text { expensive }\end{array}$ & $\begin{array}{l}\text { Biodegradation occurs during summer months unless steam is } \\
\text { supplied, soil must be accessible, land requirement is relatively } \\
\text { large, requires infrastructure }\end{array}$ \\
\hline Composting & $\begin{array}{l}\text { High microbial diversity, low capital and operating } \\
\text { costs, simple operation and design, high treatment } \\
\text { efficiency, moisture, nutrient, and pH levels can be } \\
\text { controlled, less threat than incineration, no mixing } \\
\text { with surface, shorter treatment time than } \\
\text { landfarming, can treat high concentrations of } \\
\text { organic compounds }\end{array}$ & $\begin{array}{l}\text { Large land requirement, difficulty siting, time required, possible } \\
\text { groundwater contamination, difficult to capture off-gasses }\end{array}$ \\
\hline Bioventing & Can be low cost, high efficiency & $\begin{array}{l}\text { Not suitable for VOCs, water table should be }>10 \mathrm{ft} \text { from surface, } \\
\text { not used for surficial soils, site may need to be capped, adversely } \\
\text { affected when hydraulic conductivity }<10^{-4} \mathrm{~cm} / \mathrm{s} \text {, off-gases may } \\
\text { need further treatment, should not be used near buildings } \\
\text { (explosion hazard), can be difficult to add nutrients, can take years, } \\
\text { requires underground infrastructure }\end{array}$ \\
\hline $\begin{array}{l}\text { Liquid Delivery } \\
\text { System }\end{array}$ & $\begin{array}{l}\text { Good for fractured rock aquifers, good for shallow } \\
\text { water tables }\end{array}$ & $\begin{array}{l}\text { Requires extensive site characterization, } \mathrm{H}_{2} \mathrm{O}_{2} \text { can be toxic at high } \\
\text { concentrations, longer timeframe }\end{array}$ \\
\hline
\end{tabular}

Table 9: Advantages and disadvantages of bioreactors

\begin{tabular}{|c|c|c|}
\hline \multicolumn{2}{|l|}{ Advantages } & Disadvantages \\
\hline \multicolumn{2}{|c|}{$\begin{array}{l}\text { Shorter timeframe ( } 70 \text { times faster than landfarming), less space required, } \\
\text { can be cheap, can capture VOCs, can have aerobic conditions for } \\
\text { recalcitrant compounds, simple, work on concentrated residues, can be } \\
\text { coupled with other techniques, various sizes (several liters to millions of } \\
\text { liters), economic and technical advantage for saturated soils }\end{array}$} & $\begin{array}{l}\text { Some reactors can be expensive, soil sometimes has to be } \\
\text { pretreated, require constant mixing, transportation costs, off-gases } \\
\text { likely require further treatment }\end{array}$ \\
\hline \multicolumn{3}{|c|}{ Table 10: Evaluation criteria for remediation methods } \\
\hline Applicability & Used under various situations with no or little modifi & ation \\
\hline Efficiency & $99 \%$ removal warrants 25 but $<50 \%$ warrants 0 & 25 \\
\hline Time & Removes contaminants within three months & 20 \\
\hline Cost & Inexpensive & 15 \\
\hline Cleanliness & Pollutants are not transferred to other locations & 15 \\
\hline Total score & & 100 \\
\hline
\end{tabular}

nutrients are provided by tilling the soil regularly ${ }^{[3]}$. There are several disadvantages to this form of treatment: (a) it requires a large amount of land area which can be difficult to find in populated areas, (b) it has the potential to contaminate groundwater, (c) it is sensitive to the weather, (d) it has limited capability for degrading heavier components of petroleum oils, (e) there is a chance of contaminant transport (f) it has a slow detention time and $(\mathrm{g})$ it is not suitable when volatile organic compounds (VOCs) are present because they will be released to the atmosphere ${ }^{[2,38,39]}$. However, researchers have tried this technique under wide conditions. Marin et al. ${ }^{[40]}$ used landfarming to reduce the total hydrocarbon content in an oil refinery sludge by $80 \%$ in 11 months under semiarid conditions. McCarthy et al. ${ }^{[41]}$ treated soil in Alaska contaminated with petroleum hydrocarbons (such as diesel-range organics, trimethylbenzenes, gasolinerange organics and BTEX compounds) in 55 days using landfarming. Landfarming has also been used in the degradation of oil in the desert ${ }^{[42]}$.

Biopiling: Biopiling is an ex-situ remediation method that is very effective in nutrient supplementation ${ }^{[38]}$. Biopiles require accessible contaminated soils and sufficient land area. It has been found that contaminants in biopiles show the greatest reduction in concentration over the summer months ${ }^{[43]}$. While treating diesel contaminated soil, Nano et al. ${ }^{[44]}$ found that sand improved pile porosity (and subsequently oxygen 
diffusion) and surfactants were effective in increasing contaminant bioavailability. Jørgensen et al. ${ }^{[45]}$ mixed nutrients $(\mathrm{N}, \mathrm{P}, \mathrm{K})$ and microbes in soil biopiles and found mineral oil degradation rates to be the highest in the first months, following a standard first order degradation curve.

Composting: Contaminated soil is mixed with a bulking agent such as manure or wood chips, and heaped in a large pile. Manure or sewage sludge are also used for inoculation of the pile to provide high microbial diversity, specifically mesophilic and thermophilic microbes ${ }^{[46]}$. Jørgensen et al. ${ }^{[45]}$ used bark chips as a bulking agent while composting a hydrocarbon contaminated soil in biopiles. Composting can be carried out in-situ or ex-situ to treat highly contaminated soils. Machinery is used to turn the pile (aerating it). Moisture, nutrient and $\mathrm{pH}$ levels are also controlled $^{[2]}$. Composting has a shorter detention time than landfarming and the final product can be used for landscaping. The contaminated soil is also not worked into the land so there is less potential for contaminants to enter groundwater than with landfarming. There is also less threat to air than that associated with incineration ${ }^{[2]}$. Namkoong et al. ${ }^{[46]}$ treated diesel oil contaminated soil by composting and only $2 \%$ of the total petroleum hydrocarbons were lost by volatilization.

Bioventing: Bioventing is suitable for less volatile contaminants that are biodegradable under aerobic conditions $^{[3]}$. When volatile compounds are present, off-gases need to be treated, thereby increasing the cost of the operation. This process is most applicable where the water table is greater than $3 \mathrm{~m}$ deep from the surface. The site must be capped if the soil and water table are shallow ${ }^{[43]}$. Bioventing should not be used near building because there is the potential for an explosion. Moisture levels of $40 \%-60 \%$ of field saturation must be maintained in order for the operation to be successful. Major costs are incurred in installing wells, blowers, controllers, infrastructure and other equipment. Österreicher-Cunha et al. ${ }^{[47]}$ reported that bioventing may be a valuable tool in treating gasolineethanol contaminated soil as the process appeared to accelerate soil detoxification. While treating toluene and decane contaminated soil, Malina et al. ${ }^{[48]}$ found bioventing efficiency to be dependent on temperature with respect to remediation time.

Liquid delivery systems: Liquid delivery systems require extensive site characterization and are best for sites with fractured rock aquifers, shallow water tables, formations with narrow saturated intervals, or when control of plume migration is mandated. The cost of the operation depends on the type of contaminants present, the amount and extent of contamination, sediment characteristics and source of oxygen. For example, low numbers of microbes are associated with clay soils and the addition of $100 \mathrm{mg} / \mathrm{l}$ of hydrogen peroxide as an oxygen source can be toxic to biota ${ }^{[43]}$. Flores et al. ${ }^{[49]}$ reported that hydrogen peroxide is a major source of $\mathrm{OH}$ radicals which are oxidative agents in the decomposition of hydrocarbons in the soil. Ghassemi ${ }^{[50]}$ demonstrated the in situ delivery of liquid and other treatment agents into hydrocarbon contaminated soil for the purpose of its remediation.

\section{BIOREACTORS}

There are many different types and sizes of bioreactors ranging from a vessel of a few liters to large systems that can hold millions of liters ${ }^{[43]}$. Bioreactors have a shorter detention time, lower costs than traditional physical, thermal and chemical reactors, take up less space, are simple to use, and offer an economic and technical advantage for contaminated soils having high moisture content ${ }^{[2,39,51]}$. They are divided into three categories based on the state of the medium: solid, liquid and gas bioreactors. Solid reactors can handle contaminated soil and they include static bed reactors, continuous mix reactors, horizontal drum reactors and fungal compost reactors. Liquid reactors are designed for liquid medium or slurry and they include slurryphase reactors and dual injection turbulent suspension reactors. Gas bioreactors are usually used in a combination with solid or liquid reactors to remove volatile organic contaminants from the exhaust gas of those reactors and they include a variety of biofilters and packed bed reactors.

Static Bed Reactors: A static bed reactor consists of a clay or synthetic liner, overhead irrigation system to spray water and nutrients onto the bed of excavated contaminated soil and pipes embedded in sand to collect leachate. It is a closed loop system, preventing contamination from being released to the environment. Soils contaminated with PAH compounds (naphthalene, phenanthrene, and pyrene) and pentachlorophenol were remediated using this system ${ }^{[52]}$. Diesel fuel was reduced from $683 \mathrm{ppm}$ to $81 \mathrm{ppm}$ in four months using this sustem ${ }^{[2]}$.

Continuous Mix Reactors: Continuous mix reactors allow for enhanced diesel fuel turnover in a soil mixture. They are similar to in-vessel composting systems and as such, the moisture levels should be at 50 
$\%$ of the maximum water capacity. The temperature, $\mathrm{pH}$, moisture content and aeration level can be effectively controlled in these reactors. However, this type of reactors have the potential to form pellets which reduce microbial activity and the degradation of contaminants and are associated with high equipment and operating costs ${ }^{[2]}$. Antizar-Ladislao et al.$^{[53]}$ used this system to remove 16 U.S. Environmental Protection Agency listed PAHs. Truax et al. ${ }^{[54]}$ used a continuous flow reactor to treat a diesel contaminated sandy soil.

Horizontal Drum Reactors: These are horizontal drums that rotate around on their axis like cement mixers thereby keeping soil loosely packed. Temperature, oxygen content and nutrient supply are all controlled. The advantage of these reactors is that they can be used for solid material or slurry ${ }^{[2]}$. They provide a means for performing chemical processes using high temperatures at near atmospheric pressures. However, their complexity has merely led to practical and expensive designs ${ }^{[55]}$. A Canadian consulting company (UMATAC Industrial Processes, a division of UMA Engineering Ltd) designed a horizontal drum reactor to pyrolyse oil shale into vapors ${ }^{[56]}$.

Fungal Compost Reactors: Fungal compost reactors work on the principle of bound residue formation. Indigenous peroxidase enzymes are stimulated to enhance the rate of bound residue formation. Although this form of treatment is low cost, the reactor can become carbon limited and a supplementary carbon source should be used ${ }^{[2]}$. McFarland and $\mathrm{Qiu}^{[57]}$ removed benzo( $\alpha$ )pyrene from soil using Phanerochaete chrysosporium and corn cobs as a supplementary carbon source in a fungal compost reactor. Eggen ${ }^{[58]}$ used white rot fungi (Pleurotus ostreatus) for creosote contaminated soil. This process removed $86 \%$ of the total 16 PAHs listed by the U.S. Environmental Protection Agency.

Slurry Phase Reactors: A slurry-phase bioreactor contains soil that is suspended in water by utilizing a mechanical stirrer. In these reactors, soil and water are mixed with air, nutrients and microbes. These reactors have been used in the bioremediation of soils contaminated with petroleum and its derivative PAHs. The treating time is in the order of days or weeks ${ }^{[44]}$. Saponaro et al. ${ }^{[59]}$ reported a high removal efficiency for all PAHs from soil after 23 days using a slurry system reactor. Boopathy ${ }^{[60]}$ reported that diesel biodegradation rates in a slurry reactor operating under anaerobic conditions were highest using mixed electron acceptor groups followed by sulfate reducing, nitrate reducing and methanogenic groups. Wang ${ }^{[61]}$ reported that biodegradation of naphthalene in a continuously stirred batch slurry reactor was successful.

Dual Injection Turbulent Suspension Reactors: The dual injection turbulent suspension reactor (DITS) is a modification of the slurry reactor. It has a combined airliquid injector at the bottom. Residence time is approximately 100 hours, which means that the degradation time is 70 times faster than that of landfarming ${ }^{[2]}$. Geerdink et al. ${ }^{[62]}$ found that after treatment in a DITS reactor, oil was slowly released from the contaminated soil and treatment by another method was required for a further 10 weeks to reach minimal contamination levels.

Biofilters: Biofilters are bioreactors used to remove volatile compounds from contaminated air streams. They are made from biologically active material to which the microbes can be attached such as compost or peat ${ }^{[2]}$. Because this process relies upon an established microbial population within the filter, it can be difficult to operate when mixtures vary over a short period of time $^{[3]}$. Leson and Smith $^{[63]}$ reported that biofilters remove major petroleum hydrocarbon classes (aromatics, aliphatics) to varying degrees. Maestre et al. ${ }^{[64]}$ reported that fungal biofilters are an excellent choice to treat high loads of toluene.

Packed Bed Reactors: These types of reactors are packed with growth supporting medium such as amberlite and are used to treat gas currents. A helical feed reactor optimizes conditions due to its continuous operation and long residence time. As such, treatment is rapid and the reactor is small. The process is sealed so there is no uncontrolled release of VOCs. This type of reactor allows for a quantitative estimation of the oxygen diffusion through the compacted soil ${ }^{[2]}$. Ogata et al. ${ }^{[65]}$ used a conventional packed bed reactor with ferroelectric materials to decompose benzene. Takaki et al. ${ }^{[66]}$ also used a packed bed reactor with ferroelectric pellets to remove perfluoroethane $\left(\mathrm{C}_{2} \mathrm{~F}_{6}\right)$.

\section{COMPARATIVE ANALYSES}

Remediation Methods: The advantages and disadvantages of the various nonbiological and biological remediation methods are listed in Tables 7-9 were used as the basis for the comparative analysis performed on these remediation methods. Five criteria were used to evaluate these methods: efficiency, applicability, cost, time and cleanliness. Table 1o shows 
Am. J. Applied Sci., 4 (7): 465-478, 2007

Table 11: Assessment of nonbiological remediation methods

\begin{tabular}{|c|c|c|c|c|c|c|}
\hline Criteria & $\begin{array}{l}\text { Land } \\
\text { Filling }\end{array}$ & $\begin{array}{l}\text { Soil } \\
\text { Washing }\end{array}$ & Incineration & $\begin{array}{l}\text { Thermal } \\
\text { Desorption }\end{array}$ & $\begin{array}{l}\text { Radio } \\
\text { Frequency } \\
\text { Heating }\end{array}$ & Chemcial Addition \\
\hline Applicability & 25 & 16 & 25 & 20 & 15 & 17 \\
\hline Efficiency & 25 & 20 & 25 & 15 & 15 & 15 \\
\hline Time & 0 & 25 & 25 & 15 & 15 & 15 \\
\hline Cost & 10 & 6 & 0 & 10 & 8 & 10 \\
\hline Cleanliness & 0 & 0 & 10 & 10 & 10 & 5 \\
\hline TOTAL SCORE & 60 & 67 & 85 & 70 & 63 & 62 \\
\hline
\end{tabular}

Table 12: Assessment of biological remediation methods

\begin{tabular}{|c|c|c|c|c|c|c|}
\hline Criteria & $\begin{array}{l}\text { Land } \\
\text { Farming }\end{array}$ & Biopiling & Composting & Bioventing & $\begin{array}{l}\text { Liquid } \\
\text { Delivery }\end{array}$ & Bioreactors \\
\hline Applicability & 15 & 15 & 23 & 15 & 10 & 25 \\
\hline Efficiency & 15 & 23 & 25 & 25 & 23 & 25 \\
\hline Cost & 10 & 12 & 10 & 10 & 3 & 12 \\
\hline Cleanliness & 3 & 12 & 5 & 10 & 5 & 10 \\
\hline TOTAL SCORE & 55 & 74 & 83 & 70 & 49 & 97 \\
\hline
\end{tabular}

Table 13: Advantages and disadvantages of specific solid bioreactors ${ }^{[68,69]}$

\begin{tabular}{|c|c|c|}
\hline Bioreactor & Advantages & Disadvantages \\
\hline Static Bed & $\begin{array}{l}\text { Environmentally friendly, contaminants contained, } \\
\text { temperature and gas flow control, simple; easy to } \\
\text { operate, efficiency increases with temperature }\end{array}$ & $\begin{array}{l}\text { Slow, no } \mathrm{pH} / \text { moisture control, gases may leak during } \\
\text { cleaning or maintenance, other equipment used to } \\
\text { capture volatile off gases, relatively costly }\end{array}$ \\
\hline Continuous Mix & $\begin{array}{l}\text { Enhanced turnover, consistent aeration, temperature, } \\
\mathrm{pH}, \text { moisture content and aeration effectively } \\
\text { controlled, simple hardware; easy to operate, would not } \\
\text { have to be cleaned as often as a batch reactor which } \\
\text { could reduce some costs, VOCs stored }\end{array}$ & $\begin{array}{l}\text { Expensive, can form pellets that reduce microbial } \\
\text { activity }\end{array}$ \\
\hline Horizontal Drum & $\begin{array}{l}\text { Can use high temperatures at atmospheric pressures, } \\
\text { feed can be dry or in slurry, soil stays loosely packed, } \\
\text { aiding efficiency, contaminants contained, VOCs } \\
\text { housed in the drum }\end{array}$ & $\begin{array}{l}\text { Expensive, complex, difficult to control thermal } \\
\text { reactions inside drum, may be difficult to operate based } \\
\text { on design, biofilms on the inside of the drum would be } \\
\text { difficult to clean }\end{array}$ \\
\hline Fungal compost & $\begin{array}{l}\text { Low cost, can treat a wide range of contaminants, fast } \\
\text { and efficient, contaminants contained, temperature and } \\
\text { other variables can be controlled, VOC traps }\end{array}$ & $\begin{array}{l}\text { Carbon supplementation required, cleaning, fast in } \\
\text { terms of bioreactors but will take many weeks }\end{array}$ \\
\hline
\end{tabular}

Table 14: Advantages and disadvantages of specific liquid and gas bioreactors ${ }^{[70-72]}$

\begin{tabular}{lll}
\hline Bioreactor & Advantages & Disadvantages \\
\hline Slurry Phase & $\begin{array}{l}\text { Well stirred, efficient, used in situ or ex situ, } \\
\text { contaminants contained, conditions controlled, lab } \\
\text { microcosms are cheap, easy to clean and operate }\end{array}$ & $\begin{array}{l}\text { Will need to separate solids and liquids, volatile off } \\
\text { gases must be controlled, expenses reasonable; depend } \\
\text { on pollutant concentration }\end{array}$ \\
\hline DITS & $\begin{array}{l}70 \text { times faster than landfarming, two zones; separates } \\
\text { light material from heavily polluted material - both }\end{array}$ & $\begin{array}{l}\text { Extract must be further treated for upwards of 10 weeks } \\
\text { slow, simply a modified slurry reactor, cost depends on } \\
\text { the outlet concentration of the pollutant }\end{array}$ \\
& $\begin{array}{l}\text { contained, off gases captured, bed easily removed for } \\
\text { maintenance, parameters can be controlled, simple }\end{array}$ & \\
\hline Biofilters & $\begin{array}{l}\text { Remove VOCs, simple; easy to operate, low cost, Rely on microbes, slow } \\
\text { minimal maintenance, efficient, contaminants contained, }\end{array}$ & \\
\hline temperature, pH, and moisture controlled & \\
\hline Packed Bed & $\begin{array}{l}\text { Rapid treatment, VOCs not released, parameters } \\
\text { controlled, easy to operate, minimal labor, contaminants } \\
\text { contained, low cost }\end{array}$ & could cause serious environmental or safety incidents \\
\hline
\end{tabular}


Am. J. Applied Sci., 4 (7): 465-478, 2007

Table 15: Evaluation criteria for bioreactors

\begin{tabular}{lll}
\hline Criteria & Definition & Score \\
\hline Efficiency & $95-99 \%$ removal warrants 20 & 20 \\
Time & Removes contaminants within weeks & 15 \\
Cost & Relatively inexpensive & 15 \\
Maintenance & Easy to maintain & 10 \\
Simplicity & Easy to operate & 10 \\
Release of VOCs & Non degraded VOCs are not released to the atmosphere & 10 \\
Containment of contaminants & Pollutants are not leaked out of the reactor & 10 \\
Control & Need for pH, temperature or moisture control & 10 \\
\hline TOTAL SCORE & & 100 \\
\hline
\end{tabular}

Table 16: Assessment of specific bioreactors

\begin{tabular}{lcccccccc}
\hline Criteria & $\begin{array}{c}\text { Static } \\
\text { Bed }\end{array}$ & $\begin{array}{c}\text { Continuous } \\
\text { Mix }\end{array}$ & Horizontal Drum & Fungal Compost & $\begin{array}{c}\text { Slurry } \\
\text { Phase }\end{array}$ & DITS & Biofilters & Packed Bed \\
\hline Efficiency & 10 & 15 & 12 & 10 & 10 & 10 & 10 & 5 \\
Time & 5 & 15 & 12 & 5 & 10 & 10 & 5 & 12 \\
Cost & 8 & 5 & 5 & 12 & 10 & 0 & 8 & 5 \\
Maintenance & 10 & 10 & 5 & 5 & 10 & 10 & 10 & 10 \\
Simplicity & 10 & 10 & 5 & 10 & 10 & 8 & 10 & 10 \\
Release of VOCs & 5 & 10 & 10 & 10 & 0 & 10 & 10 & 10 \\
Containment & 8 & 10 & 10 & 10 & 10 & 10 & 10 & 10 \\
Control & 5 & 10 & 2 & 10 & 5 & 8 & 5 & 0 \\
\hline TOTAL SCORE & 61 & 85 & 61 & 72 & 65 & 66 & 68 & 62 \\
\hline
\end{tabular}

the definition and scores assigned to these criteria. The final results of the comparative analysis are shown in Tables 11 and 12. Among the nonbiological remediation methods, incineration scored the highest (85) followed by thermal desorption (70). The other nonbiological remediation methods had much lower scores $(67,63,62$ and 60 for soil washing, radio frequency, chemical addition and landfilling, respectively). The analysis performed on the bioremediation methods showed that with the exception of liquid delivery and landfarming (which are used under special circumstances), they are more effective than nonbiological remediation methods (except incineration). Bioreactors scored the highest (97) followed by composting (83), biopiling (74) and bioventing (70). Bioreactors have the advantages of: (a) shorter treatment time, (b) minimum space for operation, (c) ability to capture VOCs, (d) operate under aerobic conditions for recalcitrant compounds, (e) work on very concentrated residues, (f) can be operated at various sizes, and (g) can be coupled with other techniques if so needed.

Bioreactors: The advantages and disadvantages of the various bioreactors listed in Tables 13 and 14 were used as a basis for the comparative analysis performed on the bioreactors. Eight criteria were used to evaluate these reactors: efficiency, residence time, cost, maintenance, simplicity of operation, release of VOCs to the atmosphere, containment of contaminants and control of operating parameters such as $\mathrm{pH}$, temperature and moisture control. Table 15 shows the definition and scores assigned to these criteria. The final results of the comparative analysis are shown in Table 16. Among the solid bioreactors evaluated, the continuous mix bioreactor scored the highest (85) followed by the fungal compost bioreactor (72). Both, the static bed bioreactor and the horizontal drum bioreactor scored 61 , the first suffered from the release of VOCs and the long residence time while the second had a high cost and difficulties associated with maintenance and control. The Liquid and gas bioreactors, which are usually used for specific cases, scored much lower than the continuous mix bioreactor, 62 for the packed bed reactor, 65 for the slurry-phase bioreactor, 66 for the DITS bioreactor and 68 for the biofilters.

\section{CONCLUSION}

Many of the current Canadian regulations relate to sulphur content in diesel fuel because of acid rain. Although PAHs are considered toxic under the Canadian Environmental Protection Act, there are no standards for PAHs in diesel. About 60 of Canada's contaminated sites involve petroleum hydrocarbons. The factors affecting the cost of clean up include: the accessibility to the site, weather conditions, quantity of spilled fuel, the extent of environmental damage and the time required for the clean up. The Canada-wide standards for petroleum hydrocarbons in soil separate soil into four categories based on land usage: agricultural, residential, commercial and industrial. It 
also specifies the methods and outcome for the assessment and management of contaminated sites but timelines are left for individual jurisdictions to decide.

The remediation methods included soil washing, landfilling, incineration, thermal desorption, radio frequency heating, chemical addition, landfarming, biopiling, composting, bioventing, liquid delivery and bioreactors. The advantages and disadvantages of several remediation methods were determined. Five criteria were used for the evaluation of these methodes: efficiency, applicability, cost, time and cleanliness. The results showed that the biological methods were more effective than nonbiological ones and the bioreactors scored the highest among the biological methods. Further evaluation was performed on several solid, liquid and gas bioreactors which included static bed, continuous mix, horizontal drum, fungal compost, slurry-phase, DITS, biofilters and packed bed bioreactors. Eight criteria were used for their evaluation : efficiency, time, cost, maintenance, simplicity, release of VOCs to the atmosphere, containment of contaminants and control of operating parameters. The results showed that the continuous mix bioreactor was the most effective system.

\section{ACKNOWLEDGEMENT}

The National Science and Engineering Research Council (NSERC) of Canada financially supported this study.

\section{REFERENCES}

1. Irwin, R.J., M. Van Mouwerik, L. Stevens, M. D. Seese and W. Basham, 1997. Environmental contaminants encyclopedia: Diesel Oil. National Park Service, Water Resources Division. Fort Collins, CO. Accessed October, 2006. www.nature.nps.gov/hazardsafety/toxic/diesel.pdf

$\leq$ http://www.nature.nps.gov/hazardsafety/toxic/diesel.pdf $>$

2. Riser-Roberts, E., 1998. Bioremediation of petroleum contaminated soils. lewis publishers, Boca Raton, Florida.

3. Eweis, J., S. Ergas, D. Chang and E. Schroeder, 1998. Bioremediation principles. McGraw-Hill, Toronto, Ontario.

4 Hesnawi, R. M., 2004. Impact of composting strategies on the treatment of soil contaminated with diesel fuel. PhD thesis (ISBN-978-0-61289564-5), University of Manitoba, Winnipeg, Manitoba.
5. Aikman, M. J. L., 2001. The application of petroleum engineering methods for in-situ remediation of light hydrocarbon contaminated soil: Experimental and Numerical Simulation Studies. PhD Thesis (ISBN-978-0-612-64849-4). University of Calgary, Calgary, Alberta.

6. Jones, N., 2002. Environment-Ecuador: Oil Spill Killing Galapagos Iguanas. Global Information Network. New York, New York.

7. CCME, 2001. Canada-Wide Standards for Petroleum Hydrocarbons in Soil (CWS PHCS).

Canadian Council of Ministers of the Environment, Winnipeg, Manitoba.

8. Environment Canada, 2005. Diesel Fuel. The Green Lane ${ }^{\mathrm{TM}}$. Accessed December, 2006. www.ec.gc.ca/energ/fuels/fuel home_e.htm <http://www.ec.gc.ca/energ/fuels/fuel home e.htm>

9 Guthrie, J., P. Fowler, and R. Sabourin, 2003. Gasoline and diesel fuel survey, D1 and oxygenates in gasoline, cetane index, cetane number, aromatics and PAHs in diesel. Technical Report, Oil, Gas and Energy Branch, Environment Canada, Gatineau, Quebec.

10. Blondeau, J., G. Pon, S. Bresciani, and M. Reaney, 2004. Analysis of selected diesel fuel markets in Canada. Agriculture and Agrifood Canada, Ottawa, Ontario.

11. Atlantic PIRI, 2003. Atlantic Risk Based Corrective Action for Petroleum Impacted Sites in Atlantic Canada. User Guidance (Version 2.0), Atlantic Partnership in RBCA Implementation, Halifax, Nova Scotia.

12. Haapea, P. and T. Tuhkanen, 2006. Integrated treatment of PAHs contaminated soil by soil washing, ozonation, and biological treatment. J. Hazardous Materials, 136: 244-250.

13. Viglianti, C., K. Hanna, C. de Brauer and P. Germain, 2006. Removal of polycyclic aromatic hydrocarbons from aged-contaminated soil using cyclodextrins: experimental study. Envir. Pollution, 140: 427-435.

14. Rajput, V. S., A. J. Higgins and M. E. Singley, 1994. Cleaning of excavated soil contaminated with hazardous organic compounds by washing. Water Envir. Research, 66: 819-827.

15. Isoyama, M. and S. I. Wada, 2007. Remediation of $\mathrm{Pb}$-contaminated soils by washing with hydrochloric acid and subsequent immobilization with calcite and allophanic soil. J. Hazardous Materials, (doi:10.1016/j.jhazmat.2007.01.008).

16. Jang, M., S. Hwang and S. I. Choi, 2007. Sequential soil washing techniques using hydrochloric acid and sodium hydroxide for remediating arsenic-contaminated soils in abandoned iron-ore mines. Chemosphere, 66: 8-17. 
17. Marttinen, S. K., R. H. Kettunen and J. A. Rintala, 2003. Occurrence and removal of organic pollutants in sewages and landfill leachates. The Science of The Total Environment, 301: $1-12$.

18. Fent, K., 2003. Ecotoxicological problems associated with contaminated sites. Toxicology Letters, 140-141: 353-365.

19. Gitipour, S., M. T. Bowers and A. Bodocsi, 1997. The use of modified bentonite for removal of aromatic organics from contaminated soil. J. Colloid and Interface Science, 196: 191-198.

20. Schobel, A., A. G. Class, L. Krebs, M. BraunUnkhoff, C. Wahl and P. Frank, 2001. Thermal destruction of benzene. Chemosphere, 45:591599.

21. Wang, C. H. and S. S. Lin, 2004. Preparing an active cerium oxide catalyst for the catalytic incineration of aromatic hydrocarbons. Applied Catalysis A: General, 68: 227-233.

22. Wang, C. H., 2004. $\mathrm{Al}_{2} \mathrm{O}_{3}$-supported transition metal oxide catalysts for catalytic incineration of toluene. Chemosphere, 55: 11-17.

23. Wang, C. H., S. S. Lin, C. L. Chen and H. S. Weng, 2006. Performance of the supported copper oxide catalysts for the catalytic incineration of aromatic hydrocarbons. Chemosphere, 64: 503509.

24. Arsenijević, Z. L., B. V. Grbić, N. D. Radić and Z. B. Grbavčić, 2006. Catalytic incineration of ethylene oxide in the packed bed reactor. Chemical Engineering Journal, 116: 173-178.

25. Tseng, T. K. and H. Chu, 2001. The kinetics of catalytic incineration of styrene over a $\mathrm{MnO} / \mathrm{Fe}_{2} \mathrm{O}_{3}$ catalyst. The Science of the Total Environment, 275: 83-93.

26. Everaert, K. and J. Baeyens, 2004. Catalytic combustion of volatile organic compounds. J. Hazardous Materials, 109: 113-139.

27. Andersson, T., K. Hartonen, T. Hyotylainen and M. L. Riekkola, 2002. Pressurised hot water extraction and thermal desoroption of polycyclic aromatic hydrocarbons from sediment with use of a noval extraction vessel. Analytica Chimica Acta, 466: 93-100.

28. Merino, J. and V. Bucala, 2006. Effect of temperature on the release of hexadecane

from soil by thermal treatment. J Hazardous Materials, (doi:10.1016/j.jhazmat.2006.09.050).

29. Piña, J., J. Merino, A. F. Errazu and V. Bucalá, 2002. Thermal treatment of soils contaminated with gas oil: influence of soil composition and treatment temperature. J. Hazardous Materials, 94: 273-290.
30. Al-Mayman, S. I. and S. M. Al-Zahrani, 2003. Catalytic cracking of gas oils in electromagnetic fields: reactor design and performance. Fuel Processing Tech., 80: 169-182.

31. Shih, S. I., T. C. Lin and M. Shih, 2005. Decomposition of benzene in the RF plasma environment part II. formation of polycyclic aromatic hydrocarbons. J. Hazardous Materials, 117: $149-159$

32. Rivas, F. J., 2006. Polycyclic aromatic hydrocarbons sorbed on soils: a short review of chemical oxidation based treatments. J. Hazardous Materials, 138: 234-251.

33. Goi, A., N. Kulik and M. Trapido, 2006. Combined chemical and biological treatment of oil contaminated soil. Chemosphere, 63: 1754-1763.

34. Kronholm, J., T. Kuosmanen, K. Hartonen and M. L. Riekkola, 2003. Destruction of PAHs from soil by using pressurized hot water extraction coupled with supercritical water oxidation. Waste Management, 23: 253-260.

35. Noordkamp, E. R., J. T. C. Grotenhuis and W. H. Rulkens, 1997. Selection of an efficient extraction method for the determination of polycyclic aromatic hydrocarbons in contaminated soil and sediment. Chemosphere, 35: 1907-1917.

36. Zylstra, G. J. and D. T. Gibson, 1991. Aromatic hydrocarbon degradation: a molecular approach. Technical Report \# EPA/600/J-93/325, U. S. Environmental Protection Agency, Washington DC.

37. Ghaly, A.E. and J. B. Pyke, 2001. In-vessel bioremediation of oil contaminated peat. Energy Sources, 23: 305-325.

38. McClure, N., R. Bentham and A. Pruszinski, 2000. On-site bioremediation of dieselcontaminated soil. Technical Report, Sinclair Knight Merz Consulting, New South Wales, Australia.

39. Brox, G. H. and D. E. Hanify, 1989. A new solid/liquid contact bioslurry reactor making bioremediation more cost-competitive. Paper Presented at Colorado Hazardous Waste Management Society Conference, Denver, CO.

40. Marin, J. A., T. Hernandez and C. Garcia, 2005. Bioremediation of oil refinery sludge by landfarming in semiarid conditions: influence on soil microbial activity. Envir. Res., 98: 185-195.

41. McCarthy, K., L. Walker, L. Vigoren and J. Bartel, 2004. Remediation of spilled petroleum hydrocarbons by in-situ landfarming at an artic site. Cold Regions Science and Technology, 40: 31-39. 
42. Balba, M. T., R. Al-Daher, N. Al-Awadhi, H. Chino and H. Tsuji, 1998. Bioremediation of oilcontaminated desert soil: the Kuwaiti experience. Envir. Int., 24: 163-173.

43. Anderson, W. C., 1995. Innovative Site Remediation Technology: Bioremediation. American Academy of Environmental Engineers, Annapolis, MD.

44. Nano, G., A. Borroni and R. Rota, 2003. Combined slurry and solid-phase bioremediation of diesel contaminated soils. J. Hazardous Materials, 100: 79-94.

45. Jørgensen, K. S., J. Puustinen and A. M. Suortti, 2000. Bioremediation of petroleum hydrocarbon contaminated soil by composting in biopiles. Environmental Pollution, 107: 245-254.

46. Namkoong, W., E. Hwang, J. Park and J. Choi, 2002. Bioremediation of diesel contaminated soil with composting. Environmental Pollution, 119: 23-31.

47. Österreicher-Cunha, P., E. do Amaral Vargas Jr., J. R. D. Guimarães, T. M. Pereira de Campos, C. M. F. Nunes, A. Costa, F. dos Santos Antunes, M. I. P. da Silva and D. M. Mano, 2004. Evaluation of bioventing on a gasoline-ethanol contaminated undisturbed residual soil. J. Hazardous Materials, 110: 63-76.

48. Malina, G., J. T. C. Grotenhuis and W. H. Rulkens, 1999. The effect of temperature on the bioventing of soil contaminated with toluene and decane. J. Soil Contamination, 8: 455-480.

49. Flores, R., G. Blass and V. Domínguez, 2007. Soil remediation by an advanced oxidative method assisted with ultrasonic energy. J. Hazardous Materials, 140: 399-402.

50. Ghassemi, M., 1988. Innovative in situ treatment technologies for cleanup of contaminated sites. J. Hazardous Materials, 17: 189-206.

51. McNicoll, D. and A. Baweja, 1995. Bioremediation of petroleum-contaminated soils: an innovative, environmentally friendly technology. Technical Report, The National Contaminated Sites Remediation Program, Environment Canada, Ottawa, Ontario.

52. Sims, R. C., J. L. Sims, D. L. Sorensen, J. E., McLean and S. G. Hurling, 1990. Prepared bed reactor for full scale remediation of soil contaminated with wood preserving wastes: field bioremediation evaluation. U.S. Environmental Protection Agency. Accessed October, 2006. http://www.p2pays.org/ref/37/36928.pdf
53. Antizar-Ladislao, B., J. Lopez-Real and A. J. Beck, 2006. Bioremediation of polycyclic aromatic hydrocarbons (PAH) in an aged coal-tarcontaminated soil using different in-vessel composting approaches. J. Hazardous Materials, 137: 1583-1588.

54. Truax, D. D., R. Britto and J. H. Sherrard, 1995. Bench-scale studies of reactor based treatment of fuel contaminated soils. Waste Management, 15: 351-357.

55. Sherritt, R. G., J. Chaouki, A. K. Mehrotra and L. A. Behie, 2003. Axial dispersion in the threedimensional mixing of particles in a rotating drum reactor. Chemical Engineering Sci., 58: 401-415.

56. Taciuk, W. and L. R. Turner, 1988. Development status of australian oil shale processing utilizing the Taciuk processor. Fuel, 67: 1405-1407.

57. McFarland, M. J. and X. J. Qiu, 1995. Removal of benzo( $\alpha$ )pyrene in soil composting systems amended with the white rot fungus Phanerochaete chrysosporium. J. Hazardous Materials, 42: 61-70.

58. Eggen, T., 1999. Application of fungal substrate from commercial mushroom production Pleurotus ostreatus - for bioremediation of creosote contaminated soil. International Biodeterioration and Biodegradation, 44: 117-126.

59. Saponaro, S., L. Bonomo, G. Petruzzelli, L. Romele and M. Barbafieri, 2002. Polycyclic aromatic hydrocarbons (PAHs) slurry phase bioremediation of a manufacturing gas plant (MGP) site aged soil. Water, Air, \& Soil Pollution, 135: 219-236.

60. Boopathy, R., 2003. Use of anaerobic soil slurry reactors for the removal of petroleum hydrocarbons in soil. International Biodeterioration and Biodegradation, 52: 161-166.

61. Wang, S.I., 2001. Biodegradation of naphthalenecontaminated soils in slurry bioreactors. Journal of Environmental Engineering, 127: 748-754.

62. Geerdink, M. J., R. H. Kleijntjens, M. C. M. van Loosdrecht and K. C. A. M. Luyben, 1996. Microbial decontamination of polluted soil in a slurry process. J. Environmental Engineering, 122: 975-982.

63. Leson, G. and B. S. Smith, 1997. Petroleum environmental research forum field study on biofilters for control of volatile hydrocarbons. J. Environmental Engineering, 123: 556-562.

64. Maestre, J. P., X. Gamisans, D. Gabriel and J. Lafuente, 2007. Fungal biofilters for toluene biofiltration: evaluation of the performance with four packing materials under different operating conditions. Chemosphere, 67: 684-692. 
65. Ogata, A., N. Shintani, K. Yamanouchi, K. Mizuno, S. Kushiyama and T. Yamamoto, 2000. Effect of water vapor on benzene decomposition using a nonthermal-discharge plasma reactor. Plasma Chemistry and Plasma Processing, 20: 453467.

66. Takaki, K., K. Krashima and J. S. Chang, 2006. Scale-up of ferro-electric packed bed reactor for $\mathrm{C}_{2} \mathrm{~F}_{6}$ decomposition. Thin Solid Films, 506-507: 414-417.

67. Anitescu, G. and L. L. Tavlarides, 2006. Supercritical extraction of contaminants from soils and sediments. The J. Supercritical Fluids, 38: 167180.

68. Williams, T. and R. P. Bottrill, 1995. Sulphurpolycyclic aromatic hydrocarbons in tyre pyrolysis oil. Fuel, 74: 736-742.
69. Canet, R., J. G. Birnstingl, D. G. Malcolm, J. M. Lopez-Real and A. J. Beck. Biodegradation of polycyclic aromatic hydrocarbons (PAHs) by native microflora and combinations of white-rot fungi in a coal-tar contaminated soil. Bioresource Technology, 76: 113-117.

70. Collina, E., G. Bestetti, P. Di Gennaro, A. Franzetti, F. Gugliersi, M. Lasagni and D. Pitea, 2005. Naphthalene biodegradation kinetics in an aerobic slurry-phase bioreactor. Environment International, 31: 167-171.

71. Pinkerton, B., 2006. Spatiotemporal temperature patterns of acetylene hydrogenation in a fixed bed catalytic reactor. $\mathrm{PhD}$ thesis (ISBN-978-0-54278199-5), University of Houston, Houston, Texas.

72. Kleijntjens, R. H., 1991. Biotechnological slurry process for the decontamination of excavated polluted soils. PhD thesis, Technische Universiteit Te Delft, the Netherlands. 